\title{
PREDIKSI DISTORSI HARMONISA PADA UTILITY LISTRIK PERUMAHAN YANG DISEBABKAN OLEH BEBAN NONLINIER MENGGUNAKAN STATISTIK PERBANDINGAN LINIER
}

\author{
Oleh \\ Riza Widia, Herisajani, Witrionanda
}

Staf Pengajar Teknik Elektro Politeknik Negeri Padang

\begin{abstract}
Loads of electricity utility consists of linear loads and non linear loads. The non linear loads for example TV, personal computer, VCD player, microwave and fluorescent lamp using electronics ballast. Loads with non linear characteristics become harmonic current source to electricity utility. Condition prediction used statistic linear comparison based on load power to THDi (Distortion of Harmonic Current). Measurement result using power quality analyzer and etap 4.0 (Fluke 43B) find typical THDi. The calculation and measurement result of PF and THD to loads of electricity utility show the differences less than 5\%. However power factor formulation and distortions of harmonic current is valid.
\end{abstract}

Keyword: Electricity utility, Loads, Distortion of Harmonic Current

\section{PENDAHULUAN}

Beban-beban yang terdapat pada utiliti litrik perumahan sekarang ini tidak hanya terdiri dari beban linier saja, seperti lampu pijar, pemanas air, strika dan lain sebagainya tetapi juga terdiri dari beban-beban nonlinier berupa peralatan elektronik seperti TV, komputer, tape recorder, DVD player, blenders, lampu-lampu fluorescent menggunakan ballast elektronik, motormotor listrik yang dikontrol oleh konverter statis dan lain sebagainya.

Secara umum permasalahan yang ditimbulkan oleh beban-beban linier adalah menyangkut faktor daya utiliti, sedangkan pada beban nonlinier permasalahan yang ditimbulkan adalah lebih komplek. Pada beban nonlinier (peralatan elektronik) selalu terdapat konverter berupa penyearah yang mengkonversikan tegangan bolak balik dari utiliti ke tegangan searah untuk operasi komponen elektronik. Konverterkonverter ini mempunyai karakteristik yang nonlinier, sehingga ia merupakan sumber arus harmonisa bagi utiliti listrik. Tingginya tingkat kandungan harmonisa yang terdapat pada utiliti listrik atau pada sistem distribusi tenaga listrik, dapat menyebabakan kualitas daya sistem menjadi lebih buruk, karena faktor daya sistem menjadi lebih rendah, bentuk gelombang tegangan sistem terdistorsi, rugi-rugi daya pada sistem meningkat, pemanasan lebih pada transformator, peningkatan arus netral sistem yang menyebabakan beban lebih pada konduktor netral dan penggunaan energi listrik menjadi tidak efisien [2].

Dari hasil survei CBEMA (Computer and Business Equipment Manufacturing Association) dan LCSE (Liebert Customer Service Engineering) dinyatakan bahwa lebih dari $40 \%$ total 
beban yang terdapat pada sistem distribusi tenaga listrik modern adalah berupa beban nonlinier yang didominasi oleh peralatan elektronik. Dan beban ini telah menyebabkan arus sistem terdistorsi dengan faktor daya lebih rendah dari 0.67 dan arus netralnya mencapai 1.73 kali dari arus fasanya. Beban elektronik ini meningkat terus dan diperkirakan mencapai $65 \%$ pada akhir tahun 2004. Sebagaimana diketahui bahwa setiap peralatan elektronik yang terdapat pada utiliti merupakan sumber arus harmonisa. Besar arus harmonisa yang dibangkitkannya akan proporsional terhadap kapasitas dayanya. Secara individual, arus harmonisa yang dibangkitkan oleh peralatan elektronik ini relatif kecil tetapi secara keseluruhan arus harmonisa ini menjadi signifikan bagi utiliti. Karena total beban yang terdapat pada utiliti listrik perumahan adalah gabungan dari beban-beban linier dan nonlinier, maka total distorsi arus harmonisa dan faktor daya pada utiliti juga akan dipengaruhui oleh komposisi gabungan dari kedua jenis beban tersebut. Pada paper ini dijelaskan suatu metoda pembentukan formulasi praktis untuk memprediksi distorsi arus harmonisa dan faktor daya yang terjadi pada utiliti listrik perumahan dikarenakan oleh gabungan dari beban linier dan nonlinier. Pada metoda ini, beban-beban linier dimodelkan sebagai beban tanpa kandungan harmonisa dan beban-beban nonlinier dimodelkan sebagai sumber arus harmonisa yang sebanding dengan kapasitas dayanya. Pembentukan formulasi didasarkan pada jenis dan kapasitas daya masing-masing beban yang diolah menggunakan cara statisik-perbandingan linier. Hasil prediksi ini sangat berguna untuk mengetahui kemampuan kapasitas jaringan utiliti yang ada sekarang dan sebagai antisipasi untuk pengembangan masa yang akan datang.

\section{Beban Linier}

Beban linier yang terdapat pada utility perumahan dapat dimodelkan sebagai suatu kombinasi antara resistansi dan induktansi, tampak pada gambar di bawah ini.

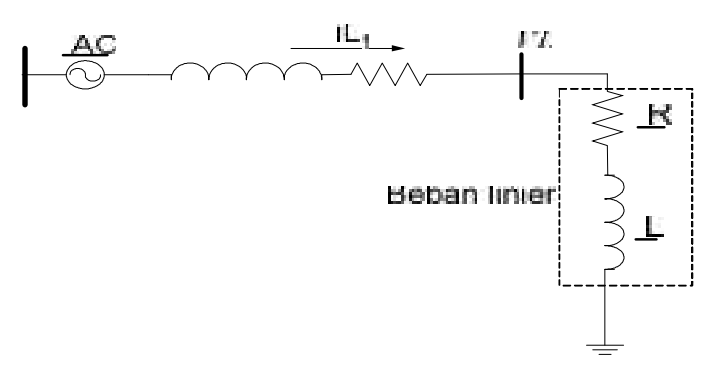

Gambar 1. Pemodelan beban linier

Apabila tegangan utility $V(t)$ diasumsikan adalah sinusoidal murni tanpa kandungan harmonisa, yaitu:

$$
\begin{aligned}
& V(t)=\sqrt{2} V_{L} \sin \omega t \ldots \ldots \ldots \ldots(1) \\
& \text { Maka arus beban } i_{L}(t) \text { juga }
\end{aligned}
$$
merupakan sinusoidal murni dengan sudut pergeseran fasa $\theta$, dapat dinyatakan sebagai berikut:

$$
i_{L}(t)=\sqrt{2} I_{L 1} \sin \left(\omega t-\theta_{1}\right) \ldots \ldots \text {.. (2) }
$$

Sehingga daya dan faktor daya pada beban utility adalah:

$$
P=V_{L} \cdot L_{L 1} \cos \theta
$$

Dimana $\cos \theta$ adalah faktor daya (PF)

beban linier.

\section{Beban Nonlinier}

Beban-beban nonlinier yang terdapat pada utility perumahan umumnya merupakan peralatan listrik elektronik satu fasa, pada peralatan elektronik ini selalu terdapat penyearah (DC Power Suply) yang berfungsi untuk merubah tegangan bolak-balik (AC) menjadi tegangan searah (DC) yang diperlukan untuk operasi peralatan tersebut. Untuk mendapatkan tegangan yang searah relative ideal, maka penyearah yang digunakan dilengkapi dengan kapasitor perata $\mathrm{C}$, atau menggunakan switch mode power suply 
(SMPS), seperti yang ditunjukkan pada gambar 2 dan gambar 3 .

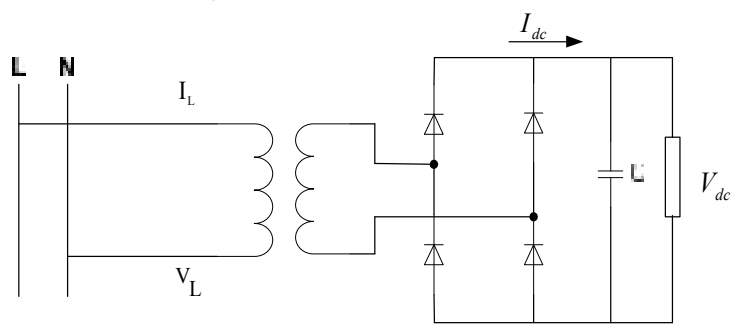

Gambar 2. Rangkaian penyearah satu fasa

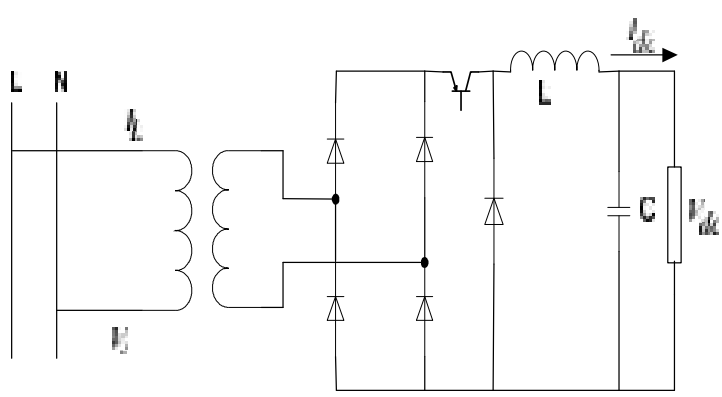

Gambar 3. Switch mode power suply (SMPS)

Karakteristik tegangan dan arus yang nonlinier dari penyearah di atas menyebabkan arus utility tidak lagi proportional terhadap tegangan, sehingga arus utility terdistorsi (nonsinusoidal) yang mengandung harmonisa.

Oleh karena itu beban nonlinier (peralatan elektronik) dapat dimodelkan sebagai satu beban linier $\mathrm{R}$ dan $\mathrm{L}$ dan sumber arus harmonisa, seperti yang ditunjukkan pada gambar di bawah ini.

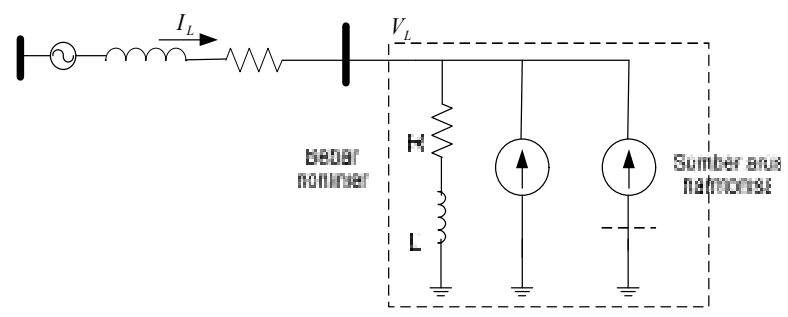

Gambar 4. Pemodelan beban nonlinier pada utility

\section{Rata-rata}

Istilah "rata-rata (average)" ini sebenarnya ini meliputi beberapa ukuran pemusatan. Rata-rata (average) adalah nilai khas yang mewakili sifat tengah, atau posisi pusat, dari suatu kumpulan data. Terdapat beberapa ukuran yang termasuk rata-rata sebagaimana yang dibahas berikut.

\section{Mean Aritmatik}

Dalam prakteknya seringkali istilah "rata-rata" mengacu pada mean aritmatik atau mean. Mean aritmatik dirumuskan sebagai berikut.

Data Tidak Terkelompok

$$
\begin{gathered}
\bar{X}=\frac{\sum_{i=1}^{n} X_{i}}{n} . \\
\mu_{x}=\frac{\sum_{i=1}^{N} X_{i}}{N}
\end{gathered}
$$

Dimana:

$\bar{X}$ : Mean aritmatika dari suatu sampel $\mu_{x}$ : Mean aritmatika dari suatu populasi

$X_{i}$ : Nilai dari suatu data

$\mathrm{n}$ : Banyaknya data $\mathrm{x}$ dari suatu sampel

$\mathrm{N}$ : Banyaknya data $\mathrm{x}$ dari suatu populasi

\section{Mean Aritmatik Terbobot}

(Weighted Arhitmetic Mean)

Sering sekali suatu persoalan, masing-masing nilai mempunyai nilai bobot / timbangan tertentu, misalnya $X_{1}$ denga timbangan $\mathrm{W}_{1}, \mathrm{X}_{2}$ dengan timbangan $\mathrm{W}_{2}$, dan seterusnya sampai $\mathrm{X}_{\mathrm{n}}$ dengan timbangan $\mathrm{W}_{\mathrm{n}}$. oleh karena itu rata yang menggunakan timbangan tersebut disebut rata-rata tertimbang (weight arihitmetic mean).

$$
\bar{X}_{w}=\frac{\sum_{i=1}^{n} W_{i} \cdot X_{i}}{\sum_{i=1}^{n} W_{i}}
$$

Dimana:

$X_{i}$ : Mean aritmatika terbobot;

$W_{i}$ : faktor pembobotan

Apabila terdapat sejumlah beban linier dan nonlinier pada utility listrik perumahan dengan kapasitas atau bobot (daya), maka dapat dibentuk suatu formulasi praktis yang dapat digunakan 
untuk memeprediksi distorsi arus harmonisa dan faktor daya total pada utility tersebut, yaitu seperti yang dinyatakan sebagai berikut:

$$
T H D_{\text {UTL }}=\frac{\sum_{n=1}\left(P_{n}\right)\left(T H D_{n}\right)}{\sum_{n=1} P_{n}}
$$

Dimana:

THD $_{\text {UTL }}$ : Total kandungan harmonisa arus pada utilitiTHD Total $_{\mathrm{n}}$ kandungan harmonisa peralatan yang termasuk beban nonlinier.

$\mathrm{P}_{\mathrm{n}} \quad$ : Kapsitas daya masingmasing peralatan listrik.

Dan faktor daya utiliti $\mathrm{PF}_{U T L}$ dapat ditentukan sebagai berikut:

$$
\mathrm{PF}_{\text {UTL }}=\left(\frac{1}{\sqrt{1+\left(T H D_{U T L}\right)^{2}}}\right) \cdot D P F_{U T L} .
$$

Dimana DPF $_{U T L}$ adalah faktor pergeseran daya utiliti yang dapat ditentukan sebagai berikut:

$$
\mathrm{DPF}_{U T L}=\frac{\sum_{n=1}\left(P_{n L}\right)\left(D P F_{n L}\right)}{\sum_{n=1}\left(P_{n L}\right)}
$$

Dimana:

$\mathrm{P}_{\mathrm{nL}}$ : Daya pada beban nonlinier

$\mathrm{DPF}_{\mathrm{nL}}$ : Faktor pergeseran daya pada beban nonlinier

Telah dijelaskan beban pada utility listrik perumahan secara umum merupakan gabungan dari jenis beban linier dan nonlinier dengan kapsitas dayanya masing-masing. Beban-beban linier akan mempengaruhui DPF, sedangkan beban nonlinier akan mempengaruhui THD dan juga DPF pada utiliti. Dengan demikian, gabungan dari kedua jenis beban ini sama-sama mempengaruhui nilai THD dan PF pada utiliti

\section{Data dan Pengukuran}

Hasil pengukuran distorsi arus harmonisa pada peralatan elektronik yang lain seperti TV, komputer dan lampu flourescent masing-masing diperlihatkan pada gambar di bawah ini.

\section{Pengukuran Daya dan Harmonisa Arus pada Beban}

Seperti kita ketahui bahwa bebanbeban yang terdapat pada utility perumahan terdiri dari beban linier dan nonlinier. Untuk itu kita akan mengelompokkan pengukuran di bawah ini berdasarkan beban linier dan nonlinier.

\section{Pengukuran Daya dan Harmonisa arus pada Beban Linier}

Pengukuran daya dan harmonisa arus pada beban linier dilakukan dengan mengukur sebuah lampu pijar. Lampu pijar merk philips dengan daya $100 \mathrm{~W}$ dan tegangan kerja 220 - 240 Volt. Nilai daya dan harmonisa arus terlihat pada gambar di bawah ini.

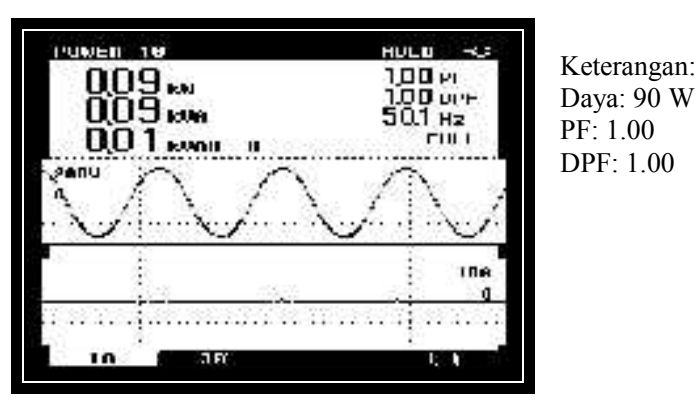

Gambar 5. Daya dari lampu pijar

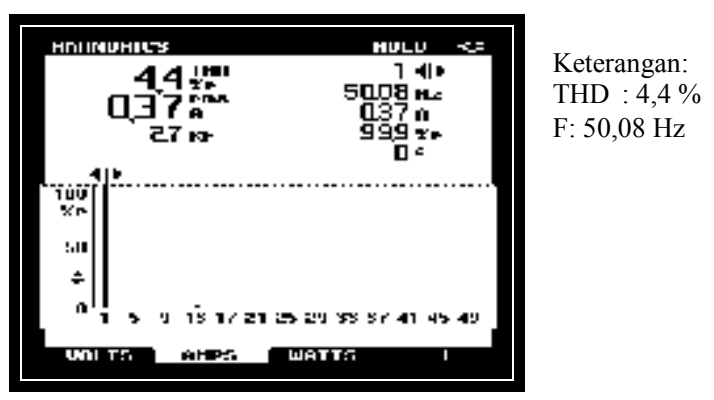

Gambar 6. Harmonisa arus lampu pijar 


\section{Pengukuran Daya dan Harmonisa pada Beban Nonlinier}

Pengukuran daya dan harmonisa arus pada beban nonlinier dilakukan dengan mengukur peralatan-peralatan elektronik yang terdapat pada utility perumahan, yaitu: lampu hemat energi (LHE), TV berwarna, water dispenser, tape recorder, dan komputer. Berikut ini susunan gambar pengukuran mulai dari lampu hemat energi dan dilanjutkan dengan peralatan yang lain.

- Lampu hemat energi (LHE)

Lampu flourescent merk Philips $23 \mathrm{~W}$, dengan tegangan kerja $170-250$ Volt.

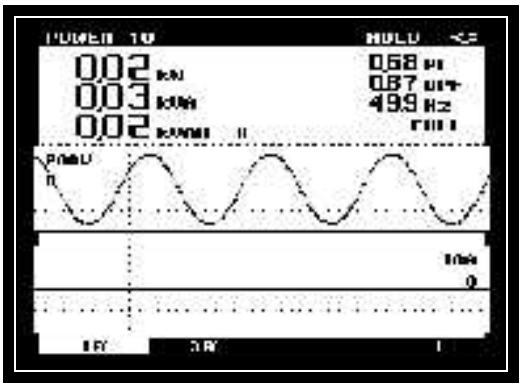

Keterangan: Daya: $20 \mathrm{~W}$ PF: 0,68 DPF: 0,87

Gambar 7. Daya lampu hemat energi (LHE)

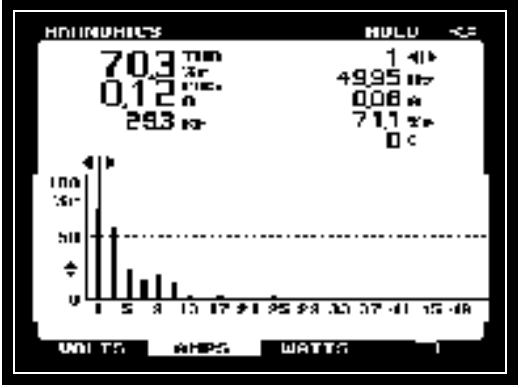

Keterangan: THD : 70,3\% F: $49,95 \mathrm{~Hz}$

Gambar 8. Harmonisa arus lampu hemat energi (LHE)

- DVD Player

Merk Toshiba memiliki daya sebesar $20 \mathrm{~W}$, dengan tegangan kerja $220-$ 240 Volt

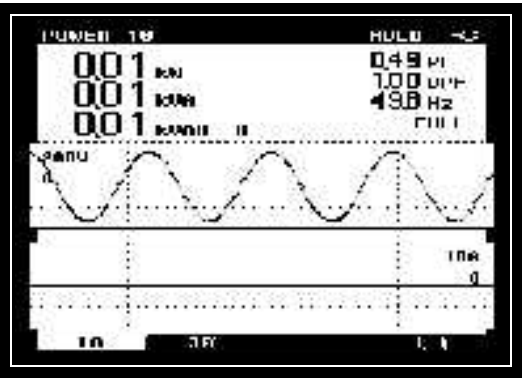

Keterangan :

Daya: $10 \mathrm{~W}$

PF: 0,49

DPF: 1,00

Gambar 9. Daya DVD Player

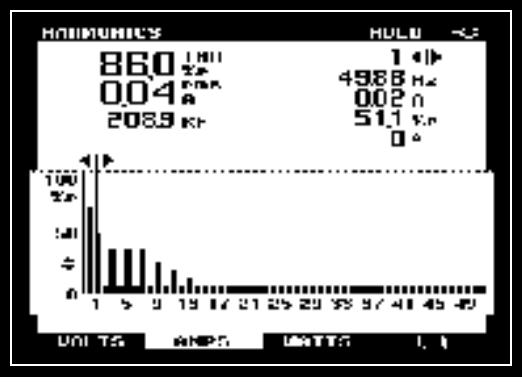

Keterangan :

THD : 86,0\%

F: $49,88 \mathrm{~Hz}$

Gambar 10. Harmonisa arus DVD

Player

- Tape Recorder

Merk Phillips Boombox memiliki daya sebesar 35 Watt, dengan tegangan kerja 110 - 220 Volt

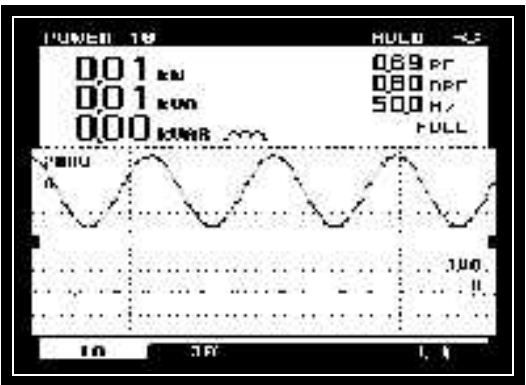

Keterangan : Daya: $10 \mathrm{~W}$ PF: 0,69 DPF: 0,80

Gambar 11. Daya Tape Recorder

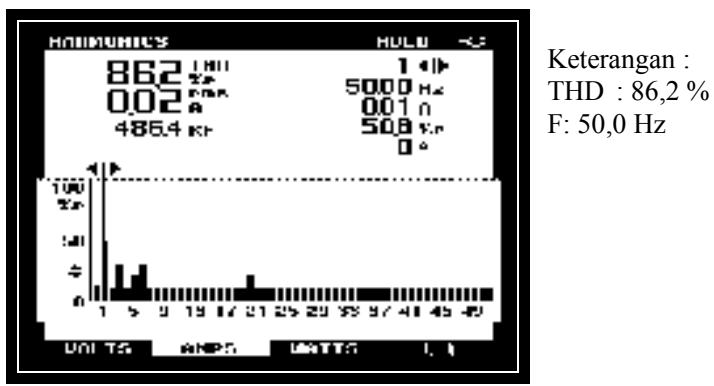

Gambar 12. Harmonisa arus Tape Recorder 
- Television 14" inchi

Televisi berwarna merk sharp 65 Watt, dengan tegangan kerja 220 230 Volt.

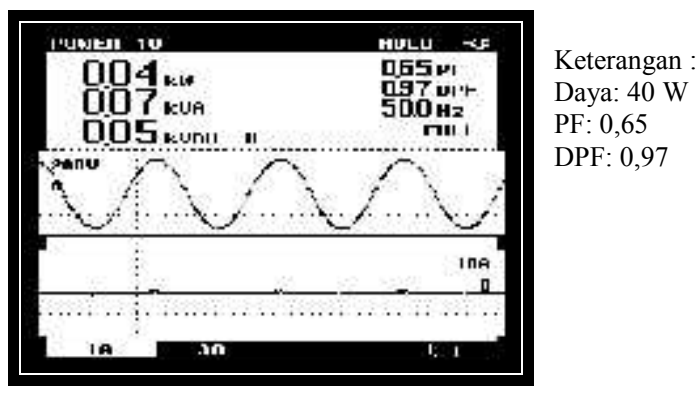

Gambar 13. Daya TV Berwarna 14"

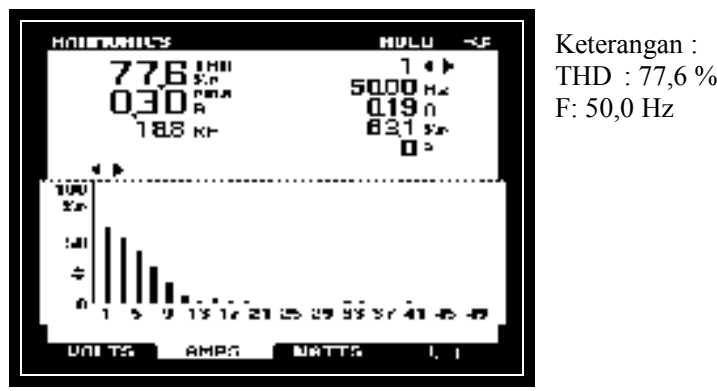

Gambar 14. Harmonisa arus TV

Berwarna14"

- Water dispenser Merk cosmos memiliki daya sebesar 350 Watt, dengan tegangan kerja 220 - 230 Volt.

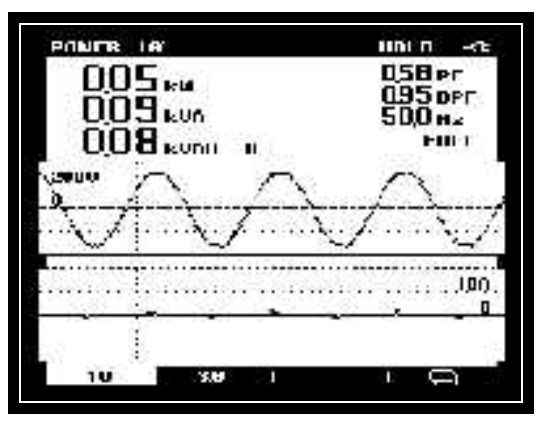

Keterangan : Daya: $50 \mathrm{~W}$ PF: 0,58 DPF: 0,95

Gambar 15. Daya water dispenser

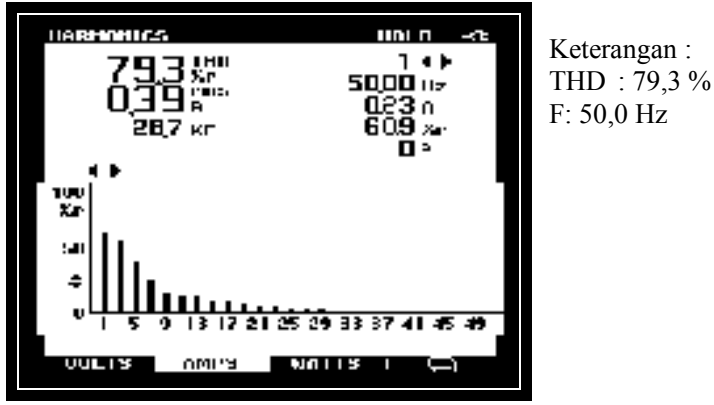

Gambar 16. Harmonisa arus water dispenser

- Personal Computer (PC)

Komputer ini memiliki supply daya sebesar 350 watt, dengan tegangan kerja 115 - 230 Volt.

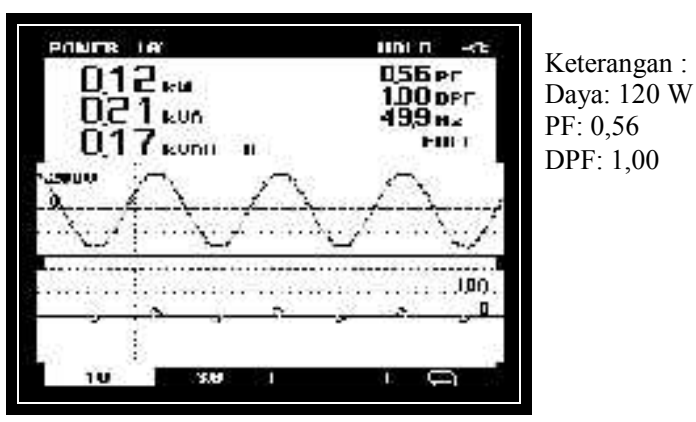

Gambar 17. Daya komputer $(P C)$

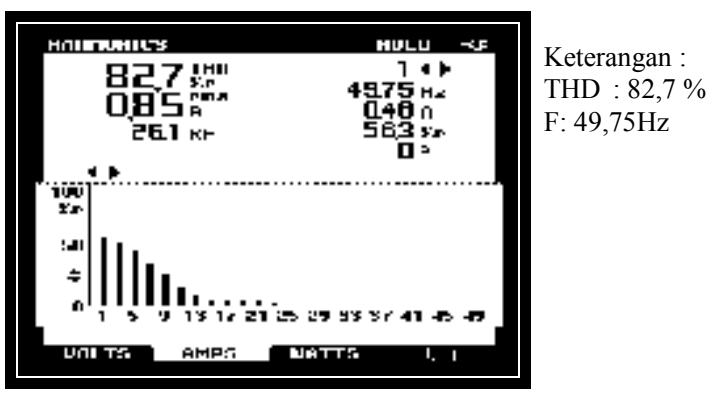

Gambar 18. Harmonisa arus komputer $(P C)$

\section{Pengukuran Daya dan Harmonisa Arus pada Utility}

Pengukuran pada utility ini berguna untuk mengetahui nilai total daya dan total harmonisa arus secara keseluruhan bila beban linier dan nonlinier digabung. Selain itu sebagai acuan untuk pembuktian rumus prediksi distorsi harmonisa menggunakan ststistik 
perbandingan linier menggunakan persamaan $2.15,2.16$, dan 2.17. Seperti terlihat pada gambar di bawah ini.

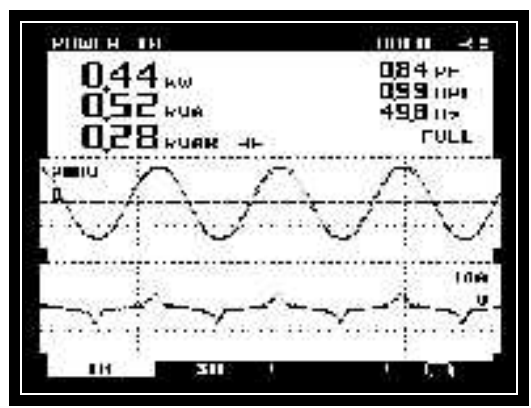

Gambar 19. Daya pada Utility

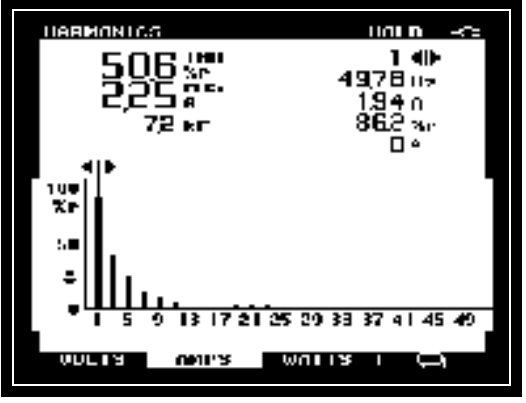

Keterangan : THD : $50,6 \%$ F: $49,78 \mathrm{~Hz}$

Gambar 20. Harmonisa arus Utility

Analisa Data dan Hasil Pengukuran

Setelah menganalisa daya dari masing-masing beban, selanjutnya menganalisa distorsi harmonisa arus $\left(T H D_{i}\right)$ untuk beban linier dan nonlinier, untuk itu maka akan dibuatkan suatu tabel di bawah ini yang akan menjelaskan jenis beban, kuantitas atau banyaknya peralatan, daya berdsarkan hasil pengukuran, total, dan $T H D_{i}$ peralatan dan utility berdasarkan hasil pengukuran.

Tabel 1. Total harmonic distortion $\left(T H D_{i}\right)$ beban

\begin{tabular}{|c|c|c|c|c|c|c|c|}
\hline $\begin{array}{l}\text { Jenis } \\
\text { beban }\end{array}$ & Peralatan & $\begin{array}{c}\text { Kuan } \\
\text { titas }\end{array}$ & $\begin{array}{l}\text { Daya } \\
\text { (Watt) }\end{array}$ & Total & PF & DPF & $\begin{array}{l}\text { THD } \\
\text { (\%) }\end{array}$ \\
\hline $\begin{array}{l}\text { Beban } \\
\text { linier }\end{array}$ & Lampu pijar & 2 & 90 & 180 & 1.00 & 1.00 & 4,4 \\
\hline \multirow{6}{*}{$\begin{array}{c}\text { Beban } \\
\text { nonlinier }\end{array}$} & $\begin{array}{c}\text { Water } \\
\text { dispenser }\end{array}$ & 1 & 50 & 50 & 0,58 & 0,95 & 79,3 \\
\hline & Lampu TL & 2 & 20 & 40 & 0,68 & 0,87 & 70,3 \\
\hline & TV & 1 & 40 & 40 & 0,65 & 0,97 & 77,6 \\
\hline & $\begin{array}{c}\text { Tape } \\
\text { Recorder }\end{array}$ & 1 & 10 & 10 & 0,99 & 0,94 & 82,7 \\
\hline & Komputer & 1 & 120 & 120 & 0,56 & 1.00 & 86,2 \\
\hline & VCD Player & 1 & 10 & 10 & 0,99 & 0,94 & 86,0 \\
\hline
\end{tabular}

Tabel 2. Total harmonic distortion

$\left(T H D_{i}\right)$ utility

\begin{tabular}{|c|c|c|c|}
\hline \multicolumn{4}{|c|}{ Utility } \\
\hline $\begin{array}{c}\text { Daya } \\
\text { (W) }\end{array}$ & PF & DPF & $\begin{array}{c}\text { THDi } \\
\text { (\%) }\end{array}$ \\
\hline 440 & 0,84 & 0,99 & 50,6 \\
\hline
\end{tabular}

Dengan mengasumsikan bahwa THD arus pada peralatan elektronik atau beban nonlinier adalah 80,3\% dengan faktor daya $\mathrm{PF}=0,86$ dan beban linier tanpa kandungan harmonisa $(\mathrm{THD}=0)$, maka dengan menggunakan formulasi yang (2.4), (2.5) dan (2.6) maka hasil perhitungan prediksi distorsi arus harmonisa adalah sebagai berikut, total 
daya peralatan listrik yang tersambung di utiliti adalah $450 \mathrm{~W}$ dan THDUTL $=49,3 \%$ dengan faktor daya PFUTL $=0,86$. Perbedaan hasil eksperimen dan hasil perhitungan relative sangat kecil, seperti yang diberikan pada Tabel 2.1.

Tabel 3. Perbandingan Hasil Prediksi dan Pengukuran

\begin{tabular}{|c|c|c|c|c|}
\hline & Daya & THD $_{\text {UTL }}$ & PF $_{\text {UTL }}$ & $\mathbf{D P F}_{\text {UTL }}$ \\
\hline Prediksi & 450 & 49,3 & 0,86 & 0,96 \\
\hline Pengukuran & 440 & 50,6 & 0,84 & 0,99 \\
\hline $\begin{array}{c}\% \\
\text { Kesalahan }\end{array}$ & 1 & 2,64 & 2,3 & 3 \\
\hline
\end{tabular}

Selain itu juga kita dapat membandingkan atau membuktikan melalui sebuah grafik yang menyatakan bahwa daya (Watt) berbanding lurus secara linier dengan besarnya distorsi harmonisa arus $\left(\mathrm{THD}_{\mathrm{i}}\right)$ dalam suatu beban utility perumahan, dimana beban tersebut terdiri dari beban linier dan nonlinier. Dengan cara menggabungkan dan mengatur antara beban linier dan nonlinier sedemikian hingga didapatkan grafik di bawah ini.

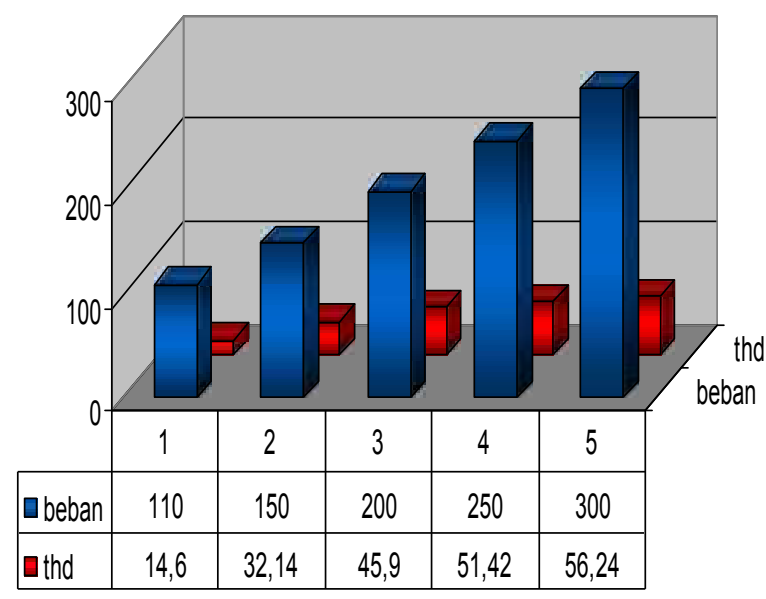

Gambar 21. Grafik Daya (P) terhadap $T H D_{i}$

Data Simulasi Menggunakan Etap 4.00

Data simulasi diperoleh dari data sekunder yang berasal dari PT. PLN (Persero) Unit Bisnis Distribusi Jawa Timur. Data dipilih berasal dari Gardu Induk Tandes dengan Penyulang Darmo Permai. Data tersebut berupa data jaringan tegangan rendah $(20 \mathrm{KV} / 380 \mathrm{~V})$ yang kemudian di olah didalam program simulasi Etap 4.00 Data tersebut meliputi hal-hal di bawah ini:

- Data Gardu Induk dan Penyulang

- Data kapasitas Trafo

- Data beban (R1/R2, S1/S2, dan B1/B2)

- Data peralatan yang umum digunakan sesuai dengan daya beban (VA)

Single line diagram untuk utility listrik pe-rumahan yang terdiri dari beban rumah tangga $(\mathrm{R})$, sosial $(\mathrm{S})$, dan bisnis (B) dapat dilihat pada gambar di bawah ini. 


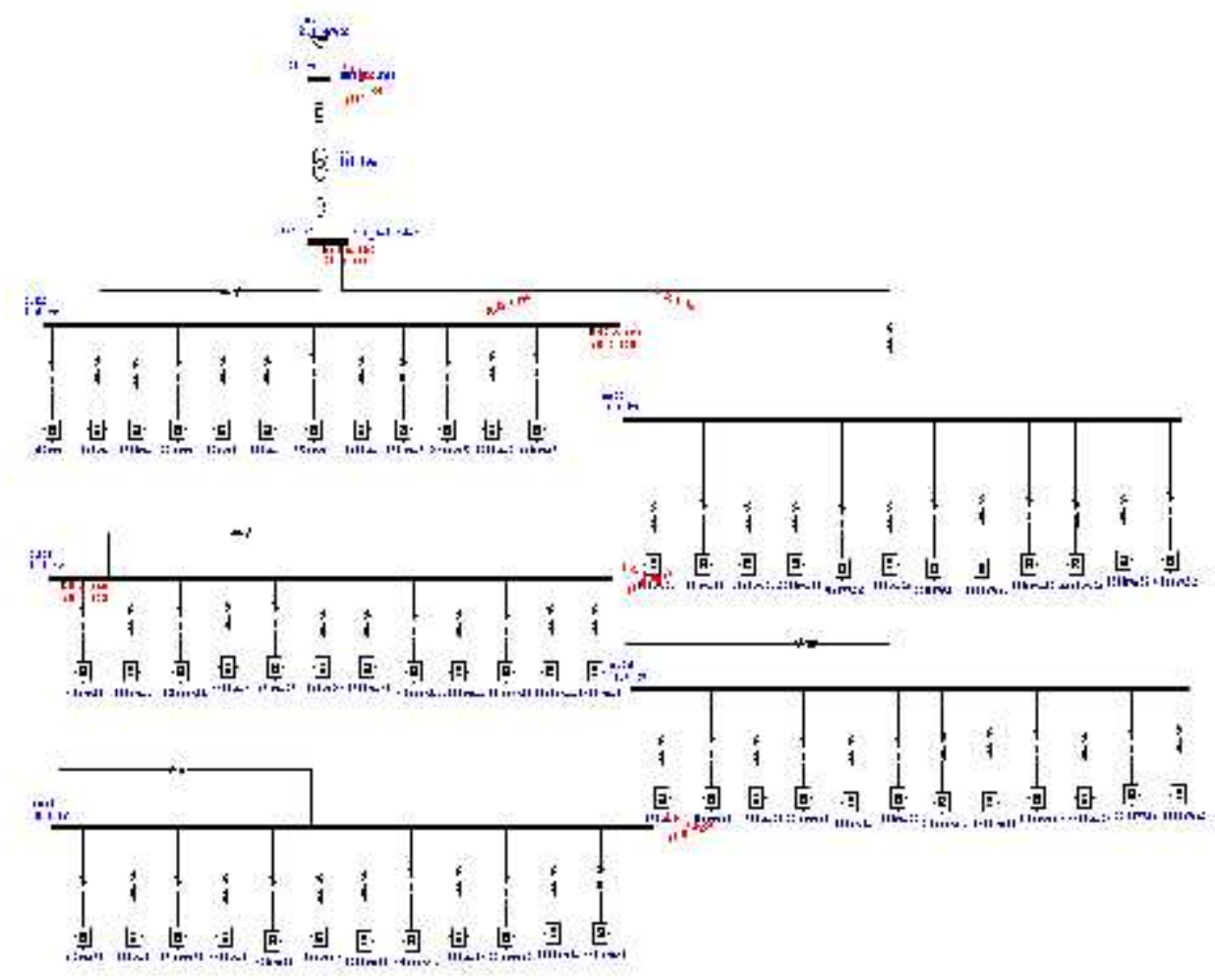

Gambar 22. single line diagram simulasi Etap 4.

\section{Analisa Harmonisa Berdasarkan} Standart IEEE 519-1992

Dari Beban di atas dapat kita peroleh nilai harmonisa arus dan tegangan setelah kita simulasikan dengan mengguanakan Etap 4.00. Untuk mengetahui batasan harmonisa arus yang diizinkan berdasarkan Standart IEEE 519-1992, sehingga kita harus mencari nilai arus hubung singkat $\left(I_{S C}\right)$ dan arus beban maksimum $\left(I_{L}\right)$ pada PCC (Point of Common Coupling) pada masing-masing bus. Setelah kita run simulasi etap, pada mode load flow untuk mendapatkan nilai arus beban maksimum dan mode hubung singkat untuk mencari nilai arus hubung singkat, maka dapat dibuatkan suatu tabel di bawah ini.
Tabel 4. Nilai $I_{S C}$ dan $I_{L}$

\begin{tabular}{|c|c|c|c|c|}
\hline Bus & $\mathbf{I}_{\mathbf{L}}(\mathbf{A})$ & $\begin{array}{c}\mathbf{I}_{\text {SC }} \\
\text { (KA) }\end{array}$ & $\mathbf{I}_{\mathbf{S C}} / \mathbf{I}_{\mathbf{L}}$ & $\begin{array}{c}\text { TDD } \\
\mathbf{( \% )}\end{array}$ \\
\hline 2 & 216,03 & 6,031 & 27,9 & 8 \\
\hline 3 & 142,06 & 5,614 & 39,5 & 8 \\
\hline 4 & 71,88 & 4,275 & 59,47 & 12 \\
\hline 5 & 145 & 6,891 & 40,63 & 8 \\
\hline 6 & 72,19 & 4,506 & 62,4 & 12 \\
\hline
\end{tabular}

Untuk masing-masing beban $\left(\mathrm{R}_{12}, \mathrm{~S}_{12}\right.$, dan $\mathrm{B}_{12}$ ) yang terhubung pada Bus yang terdapat pada tabel di atas maka nilai harmonisa arus (TDD) dapat di bandingkan dengan tabel 4.9 berdasarkan Standart IEEE 519-1992, sehingga kita dapat meprediksikan nilai TDD tersebut apakah melebihi standart yang telah ditentukan pada tabel 4.9. Untuk nilai TDD pada masing-masing beban berdasarkan kapsitas daya (450 s/d 4400 VA) dapat dilihat pada tabel 4.19. 
Tabel 5. Typical $T H D_{i}$ Beban

\begin{tabular}{|c|c|c|c|c|}
\hline Bus & $\begin{array}{c}\text { Beban } \\
\text { (VA) }\end{array}$ & $\begin{array}{c}\text { Jenis } \\
\text { Beban }\end{array}$ & $\begin{array}{c}\mathbf{T H D i}_{\mathbf{A}} \\
(\%)\end{array}$ & $\begin{array}{c}\text { THDi }_{\mathbf{B}} \\
(\%)\end{array}$ \\
\hline \multirow{6}{*}{2} & 450 & \multirow{4}{*}{$\begin{array}{l}\mathrm{R} 1, \mathrm{~S} 1, \\
\text { dan B1 }\end{array}$} & 3,41 & \multirow{6}{*}{8} \\
\hline & 900 & & 3,54 & \\
\hline & 1300 & & 7,55 & \\
\hline & 2200 & & 11,48 & \\
\hline & 3500 & \multirow{2}{*}{$\begin{array}{l}\text { R2, S2, } \\
\text { dan B2 }\end{array}$} & 17,72 & \\
\hline & 4400 & & 40,26 & \\
\hline \multirow{6}{*}{3} & 450 & \multirow{3}{*}{$\begin{array}{l}\mathrm{R} 1, \mathrm{~S} 1, \\
\text { dan B1 }\end{array}$} & 3,32 & \multirow{6}{*}{8} \\
\hline & 900 & & 3,35 & \\
\hline & 1300 & & 7,58 & \\
\hline & 2200 & \multirow{2}{*}{$\begin{array}{l}\text { R2, S2, } \\
\text { dan B2 }\end{array}$} & 11,93 & \\
\hline & 3500 & & 17,12 & \\
\hline & 4400 & & 39,89 & \\
\hline \multirow{6}{*}{4} & 450 & \multirow{4}{*}{$\begin{array}{l}\mathrm{R} 1, \mathrm{~S} 1, \\
\text { dan B1 }\end{array}$} & 3,4 & \multirow{6}{*}{12} \\
\hline & 900 & & 3,47 & \\
\hline & 1300 & & 7,6 & \\
\hline & 2200 & & 11,33 & \\
\hline & 3500 & \multirow{2}{*}{$\begin{array}{l}\text { R2, S2, } \\
\text { dan B2 }\end{array}$} & 18,62 & \\
\hline & 4400 & & 42,05 & \\
\hline
\end{tabular}

\section{Keterangan:}

- $T H D_{i A}$ adalah nilai total harmonisa arus pada setiap beban

- $T H D_{i B}$ adalah nilai total harmonisa arus pada bus yang diijinkan sesuai standart IEEE 519-1992

\section{KESIMPULAN}

Dari hasil analisa data pengukuran pada bab sebelumnya maka dapat memperkuat teori dan dapat diambil suatu kesimpulan sebagai berikut:

1. Beban nonlinier pada utility listrik listrik perumahan memiliki total kandungan distorsi harmonisa yang tinggi.

2. Pada utility listrik perumahan memiliki nilai faktor daya yang rendah dan distorsi harmonisa

\begin{tabular}{|c|c|c|c|c|}
\hline \multirow{6}{*}{5} & 450 & \multirow{4}{*}{$\begin{array}{l}\mathrm{R} 1, \mathrm{~S} 1, \\
\text { dan B1 }\end{array}$} & 3,22 & \multirow{6}{*}{8} \\
\hline & 900 & & 3,48 & \\
\hline & 1300 & & 7,54 & \\
\hline & 2200 & & 11,23 & \\
\hline & 3500 & \multirow{2}{*}{$\begin{array}{l}\text { R2, S2, } \\
\text { dan B2 }\end{array}$} & 18,85 & \\
\hline & 4400 & & 41,42 & \\
\hline \multirow{6}{*}{6} & 450 & \multirow{4}{*}{$\begin{array}{l}\mathrm{R} 1, \mathrm{~S} 1, \\
\text { dan B1 }\end{array}$} & 3,28 & \multirow{6}{*}{12} \\
\hline & 900 & & 3,46 & \\
\hline & 1300 & & 7,91 & \\
\hline & 2200 & & 11,3 & \\
\hline & 3500 & \multirow{2}{*}{$\begin{array}{l}\mathrm{R} 2, \mathrm{~S} 2, \\
\text { dan B2 }\end{array}$} & 18,77 & \\
\hline & 4400 & & 41,8 & \\
\hline
\end{tabular}

yang tinggi sebanding dengan daya.

3. Hasil perhitungan dan dibandingkan dengan hasil pengukuran diperoleh persen kesalahan (\% Error) $<5 \%$.

4. Pada simulasi tampak bahwa nilai distorsi harmonisa arus sebanding dengan daya $(\mathrm{P})$

\section{DAFTAR PUSTAKA}

Harinaldi, 2005, Prinsip-prinsip statistik untuk teknik dan sains, Jakarta: Erlangga.

Masri, Syafrudin, 2004. Pemodelan dan prediksi distorsi harmonisa utility listrik perumahan yang disebabkan oleh beban nonlinie.

IES-Politeknik Elektronika Negeri Surabaya-ITS.

Penangsang, Ontoseno, 2006,

Peningkatan kualitas daya listrik, Materi Kuliah Jurusan Teknik Elektro-ITS.

Pakpahan, Sahat, 1999, Instrumentasi 
Elektronik dan Teknik Pengukur Jakarta: Erlangga

Supranto J., 2000, Statistik, Teori, dan Aplikasi, jilid 1, edisi ke-6, Jakarta: Erlangga.

Sapiie, Soedjana, 2005, Pengukuran dan Alat Ukur Listrik, Jakarta :Pradya Paramita 